\title{
Leadership Styles and Team Performance
}

\author{
Dr. Fahad Saad Soliaman Algorabi Alharbi \\ Ministry of Education, Riyadh Alkhabra 54662, P.O. 6565 Qassim, Saudi Arabia. \\ Email address: Fahadclass1435@gmail.com
}

\begin{abstract}
:
This paper aims to study the relation between transformational leadership, transactional leadership and team performance. The researcher dependent on previous studies to conduct this research. The results refer to that transformational leadership has positive role on team performance however, transactional leadership has positive and negative role on team performance. Leaders have to strengthen the role of transformational leadership to improve and develop the team performance. For future, researcher recommended to conduct studies on transactional leadership and team performance.
\end{abstract}

Keywords: Transformational leadership, Transactional leadership, team performance

\section{Introduction}

According to Bass (1985) that transformational leadership is defined as a leader who has the power to influence his subordinates in a certain way, transformational leadership is defined as a leader who strengthens mutual cooperation and team learning with his subordinates. 
The definition of transactional leadership is inseparable from namely leadership which deals with motivating followers by calling on their personal interests (Yukl et al, 2010). Transactional leadership style can involve values, but those values are relevant to exchange processes such as honesty, responsibility, and reciprocity.

Basri et al. (2016) the definition of performance is the result or level of success of a person or overall during a certain period in carrying out his duties compared with various possibilities, such as work results, targets or targets or criteria that have been determined in advance and agreed upon.

In this current article, we set out to extend the paradigm that involves leadership styles and team performance the paper discusses some of the following key issues:

1. To study a relationship between transformational leadership and team performance.

2. To study a relationship between transactional leadership and team performance.

\section{Theoretical Background}

\subsection{Transformational Leadership}

According to Bass (1985), that transformational leadership is defined as a leader who has the power to influence his subordinates in a certain way; transformational leadership is defined as a leader who strengthens cooperation and team learning with his subordinates.

According to Yukl (2010) found that the Transformational leadership style expressed the moral values of followers in their efforts to raise their awareness about ethical issues and to mobilize their energy and resources to reform institutions. According to Bass (1985) states, that transformational leadership is leadership that goes beyond exchange or appreciation only for the performance 
shown by followers but is based more on trust and commitment (Jung and Avolio, 1999).

Transformational leaders pay attention to the development needs of each follower and problem by helping them see old problems in new ways, and they are able to motivate, nurture, awaken, awaken, and inspire followers to make extra efforts to achieve group goals. This transformational leadership is truly called true leadership because it really works towards the goals that direct the organization to goals that have never been achieved before (Locke 1997) With transformational leadership, subordinates will feel trusted, valued and subordinates will appreciate their leaders more.

Bass (1990) explains about the dimensions of transformational leadership, such as Charisma is the ability of leaders to arouse pride, trust and respect for their subordinates and able to effectively communicate the mission and vision of the organization they lead. the extent to which leaders communicate interesting visions, use symbols to focus the efforts of subordinates and express important goals in a simple way.

Intellectual stimulation, is the behavior of leaders who encourage their subordinates to always innovate and be creative in solving the problems they face, offering new ideas to stimulate their subordinates to rethink old ways of getting work done and to influence subordinates to see problems from a new perspective. Individual consideration, is the behavior of leaders who are always concerned with the development of the abilities of their subordinates, treat subordinates as individuals, to understand the desires of subordinates and function as advisors.

\subsection{Transactional Leadership}

The definition of transactional leadership is inseparable from namely leadership which deals with motivating followers by calling on their personal interests ((Burn et al,1978; Yukl et al, 2010). 
Transactional leadership style can involve values, but those values are relevant to exchange processes such as honesty, responsibility, and reciprocity. According to Bas, (1998) suggests that the relationship of transactional leaders with their subordinates is reflected in three things, The leader knows what the subordinates want and will explain what the subordinates will get if the work is in line with expectations.

The leader exchanges the efforts made by subordinates in return. Leaders are responsive to the personal interests of subordinates as long as those interests are proportional to the value of the work done by subordinates. Bass et al, (1985) also argues that the characteristics of transactional leadership consist of two aspects, contingent rewards is the leader informs his subordinates about what their subordinates must do if they want to get certain rewards and guarantees that the subordinates will get what they want in lieu of the effort done. Exception management is the leader trying to maintain the achievements and workings of his subordinates, if there is a mistake the leader immediately acts to improve it.

\subsection{Team Performance}

Basri et al. (2016) the definition of performance is the result or level of success of a person or overall during a certain period in carrying out his duties compared with various possibilities, such as work results, targets or targets or criteria that have been determined in advance and agreed upon.

Fahmi et al (2012) states that performance is the result obtained by organizations both those organizations that are profit oriented and non-profit oriented that are generated during a particular period. Performance is a complex concept that can be defined as a set of parameters or indicators that are complementary, and sometimes contradictory, that describes the assessment process through several types of achieved results (Lebas \& Euske, 2002).

In this sense, performance usually depends on identifying a causal model that describes how actions today can influence outcomes in the future. Therefore, 
performance measurement becomes an important indicator only if the organization has acquired the knowledge and mastery of its causal relationships to reproduce this result in the future. The term performance must be used to represent the sum of all processes leading to a potential or future sequence of results.

\section{Study Framework}

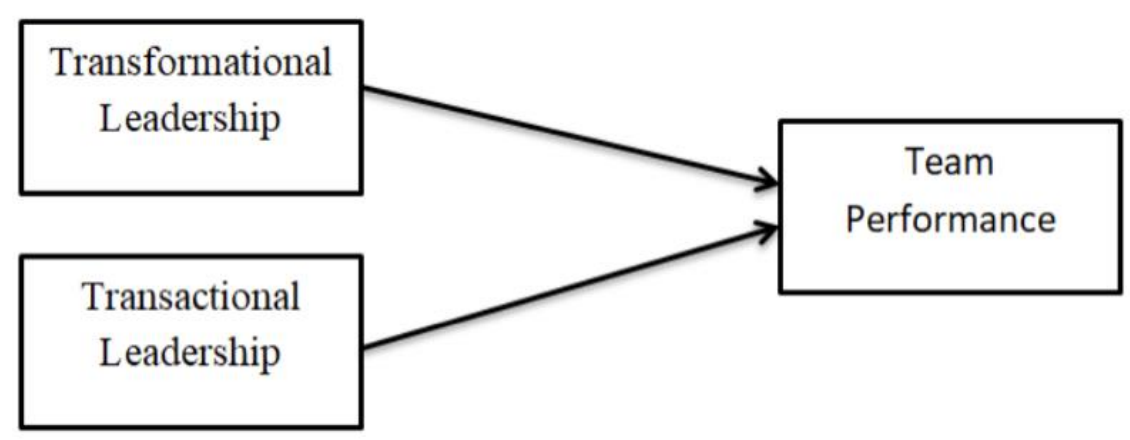

Research Framework

\section{Theoretical Framework}

\subsection{Transformational Leadership and team performance}

According to Yukl (2010) found that the Transformational leadership style expressed the moral values of followers in their efforts to raise their awareness about ethical issues and to mobilize their energy and resources to reform institutions. According to Bass (1985) states that transformational leadership is leadership that goes beyond exchange or appreciation only for the performance shown by followers but is based more on trust and commitment (Jung and Avolio, 1999).

For Dutra (2010), performance can be expressed as the set of deliverables and results generated by the development, effort and behavior of the employee in the organization. 
The level of development of the employee is related to his/her maturity and autonomy of action, and determines the organization's expectation about his/her performance. The effort, however, differs from the level of development due to the quality of the value added to the organization. Effort is a contingency, and is linked to

The motivation of the individual and the favorable conditions offered by the organization or the market, at that moment. No one can guarantee that a strenuous person today will continue to be so tomorrow. Finally, behavior may or may not affect the development and effort of the employee and is related to a pattern of behavior defined by the organization or set of people (Dutra, 2010).

Researcher is motivated to study the relationship between transformational leadership and team performance due to previous studies that recommended conducting more studies about these variables. Researcher wants to understand and analysis the relation between two important variables.

\subsection{Transactional Leadership and team performance}

Formal managers or leaders are more likely to develop mental representations that translate organizational patterns of values and beliefs (Hodgkinson \& Healey, 2008). As a result, leaders become more committed to organizational results, mainly due to their differentiated perception of the status quo. Laine, Korhonen and Martinsuo (2016) added that the social process of sense making occurs at both managerial and team levels. The other team members, although they may have a differentiated perception regarding the leader, tend to present more homogeneous patterns of behaviors and beliefs. As the simulation of Dionne, et al (2010) illustrates mental models of team members converge when there is mutual interest and leadership.

Leaders tend to emerge as different from followers in their ability to initiate and maintain interaction. 
These leaders serve to increase the participation of members with less ability, accept diverse personalities, and are very tolerant to deviations (Bass, et al 2003). In this sense, the relationship between leaders and followers creates a basis for the beginning of the studies on transactional leadership (VanSeters \& Field, 1990). The transactional leader is a negotiator, who establishes agreements in exchange for desired results. The transactional leader can both reward for satisfactory performance and punish unmet goals (Fonseca, Porto \& Barroso, 2012). Transactional leadership was mostly ineffective, while passive/avoidant leadership had complicated relationships with team performance that were both positive (direct) and negative (indirect through competence) ,(Kindarto, Zhu \& Gardner,2020).

\section{Discuss}

Transformational leadership was associated with a higher level of team cohesiveness, as compared to transactional leadership. (Stashevsky \& Koslowsky,2006). Transformational leadership influenced team performance through the mediating effect of team potency. (Schaubroeck, K. Lam \& E. Cha,2007). Based on (Purwanto et al ,2020) study's shows that the transformational leadership style has a positive and strongly significant effect on the performance of puskesmas employees and the transactional leadership style also has a strongly significant and positive effect on puskesmas team performance.

(Liu \& Wang, 2019) also explained activities needed to increase team performance which supported the results of this study that TL affect the performance of the team. Four factors of transformational leadership (II,IM,IS,IC) creates consistent way to increase team performance(Dionne et al., 2015). (Saleem et al ,2021 ) found that transformational leadership has significant association with team performance. (Abudaqa et al, 2020) found the leadership style have positive nexus with team performance. 
(Nguyen et al 2017) found that transformational leadership has positive nexus with the team performance. The results indicate that leaders feel that team performance is directly influenced by transformational leadership but for the followers, the level of team performance is directly influenced by the transactional characteristics of the leaders and not transformational characteristics. Said by ( DIAS \& BORGES,2016).

The study of (Idris \& Adi, 2018), found that all transformational leadership dimensions have a direct effect on team performance. The results indicated individual-focused transformational leadership has a positive effect on team members' performance through sequential mediation of followers' selfefficacy and individual regulation process.( $\mathrm{Lu} \mathrm{\&} \mathrm{Li}, 2021)$. They found that transformational leadership was directly and indirectly related to team performance in the expected positive directions.

Transactional leadership was mostly ineffective, while passive/avoidant leadership had complicated relationships with team performance that were both positive (direct) and negative (indirect through competence), (Kindarto, Zhu \& Gardner,2020). The results indicate that transformational leadership has a direct positive relationship with team performance (Anselmann \& Mulder,2020).The study of (Tabassi et al,2017) refers that the transformational leadership behavior of team leaders correlates in a positive direction with team performance.

From the results of the previous studies, it became clear that transformational leadership has a greater role in the cohesion of team compared to transactional leadership. Also, transformational leadership has a large and positive role in team performance as mentioned in previous studies, but some studies refer that transactional leadership has positive role on team performance however, other studies mentioned that transactional leadership has negative role on team performance . 
From these results, leader must strengthen the role of transformational leadership in order for the team's performance to be according to what we expect and more, and for future, researchers have to review what the cause of the negative and positive impact of the transactional leadership on team performance , which mentioned in some studies, in order to enhance the positive role that strengthen team performance and avoid the negative role that weakens performance of team .

\section{Conclusion}

This paper investigate in the role of transformational leadership and transactional leadership on team performance. The result of previous studies refer that transformational leader ship has positive role on team performance on other hand transactional leadership has positive and negative role on team performance. Leaders have to strengthen the role of transformational leadership to improve and develop the team performance. For future research, recommended to conduct research in a quantities method in different cultures or organisations to determine the role of transactional leadership is it positive or negative, and use another type leadership to compare with transactional leadership.

\section{References}

1. Abudaqa et al,( 2020), the role of leadership styles in encouraging and improving team performance in one of the biggest oil \& gas group of companies in abu dhabi, UAE .International Journal of Economics, Business and Accounting Research (IJEBAR) International Journal Vol-4, Issue-2, 2020 (IJEBAR).

2. Anselmann \& Mulder,(2020), transformational leadership, knowledge sharing and reflection, and work teams' performance: a structural equation modelling analysi. doi: 10.1111/jonm.13118.

3. Basri et al. (2016), the effect of organizational commitment, competence on job satisfaction and employees performance in maluku governor's office. iosr journal of business and management. 
4. Bass, (1990). from transactional to transformational leadership: learning to share the vision. organizational dynamics. https://doi.org/10.1016/00902616(90)90061-s.

5. Bass, B. M. (1985). leadership and performance beyond expectations. new york.

6. Bass, B. M. (1998). transformational leadership: industrial, military and educational impact. mahway, nj: lawrence erlbaum associates.

7. Bass, B. M., Avolio, b. j., Jung, d. i., \& Berson, y. (2003). predicting unit performance by assessing transformational and transactional leadership. journal of applied psychology, 88(2), 207-218. doi: http://doi.org/10.1037/ 0021-9010.88.2.207.

8. Burns, J. M. (1978). leadership. New York, NY: Harper \& Row.

9. Dias \& Borges,(2016), performance and leadership style:when do leaders and followers disagree? mackenzie management review (revista de administração mackenzie - ram), 18(2) • são paulo, sp • mar./apr. 2017.

10. Dionne, S. D., Sayama, H., Hao, C., \& Bush, B. J. (2010-2015). the role of leadershipin shared mental model convergence and team performance improvement an agent-based computational model. the leadership quarterly, 21(6).

11. Dutra, J. S. (2010). competências: conceitos e instrumentos para a gestão de pessoasna empresa moderna. são paulo: atlas.

12. Fahmi et al (2012) ,distribution of tropical eel genus anguilla in indonesia water based on semi-multiplex pcr indonesian aquaculture journal.

13. Fonseca, A. M. De o., Porto, j. b., \& Barroso, a. c. (2012). o efeito devalores pessoais nas atitudes perante estilos de liderança. revista de administração mackenzie, 13(3), 122-149 .

14. Hodgkinson, G. P., \& Healey, M. P. (2008). cognition in organizations. annual review of psychology, 59(1), 387-417. doi: http://doi.org/10.1146 annurev.psych.59.103006.093612. 
15. Idris \& Adi, (2018), transformational leadership and team performance: the role of innovation in indonesia property agent industry. advances in economics, business and management research, volume 101.

16. Jung, D. I., \& Avolio, B. J. (1999). effects of leadership style and followers' cultural orientation on performance in group and individual task conditions. academy of management journal, 42(2), 208-218. doi: http://doi.org/10.2307/257093.

17. Kindarto, Zhu \& Gardner,(2020), full range leadership styles and government it team performance: the critical roles of follower and team competencehttps://doi.org/10.1080/15309576.2020.1730198.

18. Laine, T., Korhonen, T., \& Martinsuo, M. (2016). managing program impacts in new product development: an exploratory case study on overcoming uncertainties. international journal of project management, 34(4), 717-733.

19. Lebas, M., \& Euske, K. (2002). a conceptual and operational delineation of performance. in a. d. neely (ed.). business performance measurement: theory and practice. new york: cambridge university press.

20. Liu \& Wang. (2019). a multi-level model of commitment-based human resource practices on team performance : the team cognition model. (151). https://doi.org/10.1111/1744-7941.12220.

21. Locke, (1997). participation in decision making: an information exchange perspective. in g. r. ferris (ed.), research in personnel and human resources management, vol. 15 (p. 293-331). elsevier science/jai press.

22. Lu \& Li, (2021), the dual effect of transformational leadership on individualandteam-level performance: the mediational roles of motivational processes. original research published: 17 march 2021.

23. Nguyen, T. T, Mia, 1., Winata, 1., \& Chong, V. K. (2017). effect of transformational-leadership style and management control system on managerial performance. journal of business research, 70, 202-213. 
24. Purwanto et al ,(2020), effect of transformational and transactional leadership style on public health centre performance. journal of reseacrh in business, economics, and education volume 2 e-Issn 2686-6056 issue 1 February 2020.

25. Purwanto et al ,(2020), innovation in leadership and team performance: evidence from Indonesia property agent industry.

26. Saleem et al ,(2021), a journey to cherish; how transformational leadership affects project success through team performance. psychology and education (2021) 58(1): 1156-1166.

27. Schaubroeck, K. Lam \& E. Cha, (2007), embracing transformational leadership: team values and the impact of leader behavior on team performance. journal of applied psychology. 2007, vol. 92, no. 4, 1020-1030.

28. Stashevsky \& Koslowsky,(2006), leadership team cohesiveness and team performance. international journal of manpower • january 2006.

29. Tabassi et al,(2017), linking team condition and team performance: a transformational leadership approach. project management journal, vol. 48, no. 2, 22-38. published online at www.pmi.org/pmj .

30. Van Seters, D. A., \& Field, R. H. G. (1990). the evolution of leadership theory. journal of organizational change management, 3(3), 29-45 .

31. Yukl.(2010). why flexible and adaptive leadership is essential. consulting psychology journal: practice and research, 62(2), 81-93. https://doi.org/10.1037/a0019835

Copyright (C) 2021 Dr. Fahad Saad Soliaman Algorabi Alharb, AJRSP. This is an openaccess article distributed under the terms of the Creative Commons Attribution License (CC BY NC).

Doi: doi.org/10.52132/Ajrsp.e.2021.264 